\title{
Analisis Prioritas Penanganan Ruas Jalan Strategis Untuk Pengembangan Wilayah di Kabupaten Demak
}

\author{
Natalia Eka Setya Krismawati ${ }^{1}$ \\ Direktorat Jenderal Bina Marga, Kementerian Pekerjaan Umum, Jakarta
}

Artikel Masuk : 06 Juni 2014

Artikel Diterima : 26 Juni 2014

\begin{abstract}
Abstrak: Tujuan penelitian ini adalah untuk menentukan prioritas penanganan ruas jalan strategis di Kabupaten Demak, serta untuk mengetahui penanganan ruas jalan strategis yang terjadi di lapangan untuk pengembangan wilayah di Kabupaten Demak. Data primer diperoleh berdasarkan kuesioner terhadap 11 orang tenaga ahli dalam bidang penanganan jalan. Teknik pengumpulan data dilakukan melalui korespondensi, dan daftar pertanyaan (questionaire), sedang analisis data dilakukan dengan metode AHP menggunakan program Expert Choice. Bentuk umum yang digunakan dalam penelitian ini adalah dengan teknik Analisis Rasio Manfaat-Biaya (Benefit Cost Ratio), yang dibentuk oleh dua hirarki yaitu hirarki yang berhubungan dengan Evaluasi Manfaat (KAD, PHD, KTBO dan PWT), serta yang berhubungan dengan Evaluasi Biaya (BI, BOP serta BPL). Berdasarkan hasil penilaian responden melalui kuesioner, ruas jalan strategis di Kabupaten Demak antara lain jalan Mranggen-Bulusari, jalan Karangawen-Pamongan, jalan Gajah-Dempet, jalan Demak-Bonang, dan jalan Bengkal-Karanganyar. Sedangkan hasil analisis dengan metode AHP menggunakan program Expert Choice diperoleh bahwa variabel terpenting dari Kriteria Manfaat adalah KTBO, lalu untuk Kriteria Biaya, variabel terpentingnya ialah BOP. Kemudian dengan membandingkan hasil Kriteria Manfaat Menyeluruh dengan hasil Kriteria Biaya Menyeluruh diperoleh 3 (tiga) ruas jalan strategis yang Rasio Manfaat-Biaya (Benefit-Cost Ratio) lebih besar dari satu $(B / C>1)$ yaitu jalan Mranggen-Bulusari, jalan Karangawen-Pamongan, dan jalan Gajah-Dempet. Maka dapat disimpulkan bahwa menurut hasil analisis di atas, dengan eksisting di lapangan yang melibatkan pengambil kebijakan terdapat perbedaan, dimana jalan Muka Kabupaten, jalan Menco-Jetak, jalan Gajah-Dempet, jalan Demak-Bonang, dan jalan Trengguli-Demung menjadi prioritas penanganan jalan strategis tahun 2013 oleh Pemerintah Kabupaten Demak. Artinya masih ada beberapa hal yang ditentukan oleh pihak-pihak tertentu sehingga hasil dari keputusan yang diambil belum sepenuhnya murni hasil pendekatan ilmiah yang terstruktur, dan beberapa masih bersifat subyektif.
\end{abstract}

Kata kunci: Analytical Hierarchy Process (AHP), Analisis Prioritas, Jalan Strategis.

Abstract: Purpose of this study is to determine the priority handling strategic road in Demak, and to investigate the strategic road management applications that occur in the field of the development of the region in Demak. Primary data were obtained by questionnaire to 11 experts in the field of road handling. Data was collected through correspondence, and a list of

\footnotetext{
${ }^{1}$ Korespondensi Penulis: Subdit Kebijakan \& Strategi, Direktorat Bina Program, Direktorat Jenderal Bina Marga, Kementerian Pekerjaan Umum, Jakarta, Indonesia

Email: nataliaeka_st@yahoo.com
} 
questions (questionaire), the data analysis was performed by using the AHP Expert Choice program. A common form used in this study is the technique of Benefit-Cost Ratio Analysis (Benefit Cost Ratio), which is formed by two hierarchy is a hierarchy that is associated with Benefit Evaluation (KAD, PHD, and PWT), as well as associated with Evaluation Costs (BI, $B O P$ also BPL). Based on the results of the assessment by questionnaire respondents, strategic road at Demak District such as Mranggen-Bulusari road, Karangawen-Pamongan road, Gajah-Dempet road Demak-Bonang road, and Bengkal-Karanganyar road. While the results of the analysis using the AHP method Expert Choice program found that the most important variable is KTBO for Criteria Benefits, then Costs for Criteria, the BOP is the most important variable. Then by comparing the results with the results of the Comprehensive Benefit Criteria with Criteria Comprehensive Cost obtained three (3) strategic roads which Benefit-Cost Ratio (Benefit-Cost Ratio) is greater than one $(B / C>1)$, namely MranggenBulusari road, Karangawen-Pamongan road, and Gajah-Dempet road. It can be concluded that according to the results of the above analysis, the existing field involving policy makers there is a difference, where Muka Kabupaten road, Menco-Jetak road, Gajah-Dempet road, Demak-Bonang road, and Trengguli-Demung road became a priority handling strategic road at 2013 by Demak Government. Meaning that there are still some things that are determined by certain parties that result from decisions made not entirely pure scientific approach structured results, and some are still subjective.

Keywords: Analytical Hierarchy Process (AHP), Priority Analysis, Strategic Road,

\section{Pendahuluan}

Pada prinsipnya semua jalan mantap setiap tahunnya harus mendapatkan prioritas untuk ditangani dengan pemeliharaan rutin, dan atau berkala sedangkan jalan tidak mantap memerlukan penanganan rehabilitasi, perbaikan maupun pekerjaan rekonstruksi. Di Kabupaten Demak, menurut kondisinya, untuk jalan Kabupaten 286,351 km dalam kondisi baik, untuk 45,349 km dalam kondisi sedang, sebanyak 76,222 km dalam kondisi rusak, dan $18,088 \mathrm{~km}$ dalam kondisi rusak berat. Sehingga hampir sebanyak $40 \%$ jaringan jalan yang tidak mantap tersebut memerlukan dana yang besar untuk pekerjaan berat yang biasanya melebihi kebutuhan dana yang tersedia. Karenanya diperlukan suatu sistem untuk menyaring, dan menyusun urutan prioritas penanganan.

Berbagai upaya yang dilakukan Pemerintah Kabupaten Demak saat ini namun masih belum optimal. Hal ini karena berbagai kendala yang muncul antara lain adalah pembangunan, dan pemeliharaan prasarana jalan membutuhkan modal (dana) yang sangat besar, serta waktu pengembalian modal yang panjang, dan penggunaan lahan yang cukup luas. Selain hal tersebut di atas, pembangunan, dan pengembangan infrastruktur jalan yang umumnya disusun berdasarkan skala kebutuhan, dan kemendesakan, kini keputusannya didominasi oleh pihak-pihak tertentu dalam penetapan penentuan kegiatan penanganan jalan tanpa didasari pertimbangan-pertimbangan objektif sehingga sering terjadi perubahan prioritas penanganan jalan. Untuk itu diperlukan suatu sistem untuk dapat mengurangi subyektifitas para pengambil keputusan. Salah satu metode ilmiah yang dimaksud ialah Analytical Hierarchy Process (AHP) yang dapat membantu kerangka berpikir manusia dalam memecahkan suatu masalah yang kompleks, dan tidak terstruktur melalui sebuah hirarki fungsional dengan input utama persepsi manusia. Oleh karena banyaknya ruas jalan yang harus ditangani Pemerintah Kabupaten Demak maka perlu prioritas penanganan ruas jalan agar alokasi penggunaan dana yang terbatas menjadi efektif, dan efisien penggunaannya, serta bermanfaat bagi pembangunan ekonomi sosial masyarakat, dan pengembangan wilayah di Kabupaten Demak 
Berdasarkan uraian pada latar belakang di atas, maka yang menjadi permasalahan penelitian ini adalah bagaimana menentukan skala prioritas penanganan ruas jalan strategis serta bagaimana prioritas penanganan jaringan jalan strategis di lapangan untuk pengembangan wilayah di Kabupaten Demak. Sedangkan tujuan dari penelitian ini adalah untuk menentukan prioritas penanganan ruas jalan strategis di Kabupaten Demak, serta untuk mengetahui aplikasi prioritas penanganan ruas jalan strategis yang terjadi di lapangan untuk pengembangan wilayah di Kabupaten Demak.

Pembahasan penelitian ini dibatasi pada penyusunan model pengambil keputusan menggunakan metode AHP (Analytical Hierarchy Process) dengan teknik Rasio ManfaatBiaya terhadap indikator kelancaran aksesibilitas antar daerah, peningkatan hubungan antar daerah, kelancaran transportasi barang dan orang, serta penghematan waktu tempuh yang diperoleh lewat kuesioner penilaian responden. Penilaian kuesioner dilakukan oleh tenaga ahli bidang jalan (perencanaan, pelaksanaan, dan pengawasan) dalam penentuan prioritas, dan penanganan ruas jalan strategis yang terjadi di Kabupaten Demak, sehingga diperoleh beberapa ruas jalan strategis, ranking prioritas penanganan ruas jalan strategis Kabupaten Demak, dan bagaimana aplikasinya, apakah keputusan prioritas ruas jalan yang diharapkan untuk ditangani sudah sesuai dengan proyek di lapangan.

\section{Metode Penelitian}

Penelitian ini menggunakan metode kualitatif dalam rangka mendapatkan analisa yang lebih mendalam mengenai realita yang terjadi di lapangan. Metode kualitatif lebih mudah dalam melakukan penyesuaian apabila dihadapkan pada kenyataan ganda, dan dapat menyajikan secara langsung interpretasi peneliti, dan responden sendiri selain lebih peka, dan adaptif dengan berbagai pengaruh yang terjadi terhadap pola, aspek atau nilai yang dihadapi secara empirik (Moleong, 2006). Dalam perkembangannya, untuk dapat menjawab tujuan penelitian ini, dilakukan dengan metode Analytical Hierarchy Process (AHP). Bentuk umum dari model AHP yang digunakan dalam penelitian ini adalah AHP untuk Analisis Rasio Manfaat-Biaya (Benefit Cost Ratio). Dilakukan dengan membandingkan prioritas manfaat menyeluruh terhadap prioritas biaya menyeluruh (Mulyono, 1996). Hasil perbandingan prioritas manfaat menyeluruh terhadap prioritas biaya menyeluruh ini selanjutnya digunakan untuk menentukan ranking prioritas penanganan jalan. Karena dalam penelitian ini menggunakan teknik Analisis Rasio Manfaat-Biaya, maka dalam penelitian ini dibentuk model 2 (dua) hirarki. Hirarki pertama adalah hirarki yang berhubungan dengan Evaluasi Manfaat (benefit) dari ruas jalan terpilih sesuai dengan kriteria yang digunakan, dan hirarki kedua adalah hirarki yang berhubungan dengan Evaluasi Biaya (cost).

Untuk Kriteria Manfaat yang digunakan dalam menetapkan prioritas penanganan jalan-jalan strategis di Kabupaten Demak terdiri atas 4 (empat) sub-kriteria yaitu ; (1) Kemudahan Aksesibilitas antar Daerah (KAD), (2) Peningkatan Hubungan antar Daerah (PHD), (3) Kelancaran Transportasi Barang, dan Orang (KTBO), (4) Penghematan Waktu Tempuh (PWT). Sedang Kriteria Biayanya terdiri atas 3 (tiga) sub-kriteria, yaitu ; (1) Biaya Investasi (BI), (2) Biaya Operasional, dan Perawatan Jalan (BOP), (3) Biaya Penanganan Lingkungan (BPL).

Menggunakan pendekatan Geertz (1973) yang memaknai model penelitian kualitatif lebih fokus mencari "makna" bukan mencari hukum, berupaya memahami, bukan mencari teori. Adapun model ekstraksi proses pembangunan analisis menekankan penemuan teori dari data observasi empirik di lapangan dengan metoda induktif (menemukan teori dari sejumlah data), generatif yaitu menggunakan data sebagai evidensi, konstruktif menemukan konstruksi teori atau kategori lewat analisis, dan proses mengabstraksi, serta 
subyektif yaitu merekonstruksi penafsiran, dan pemaknaan hasil penelitian berdasarkan konseptualisasi masyarakat yang dijadikan subyek studi (Sudira, 2009). Pendekatan tersebut memungkinkan peneliti untuk mengeksplorasi dengan lebih dalam.

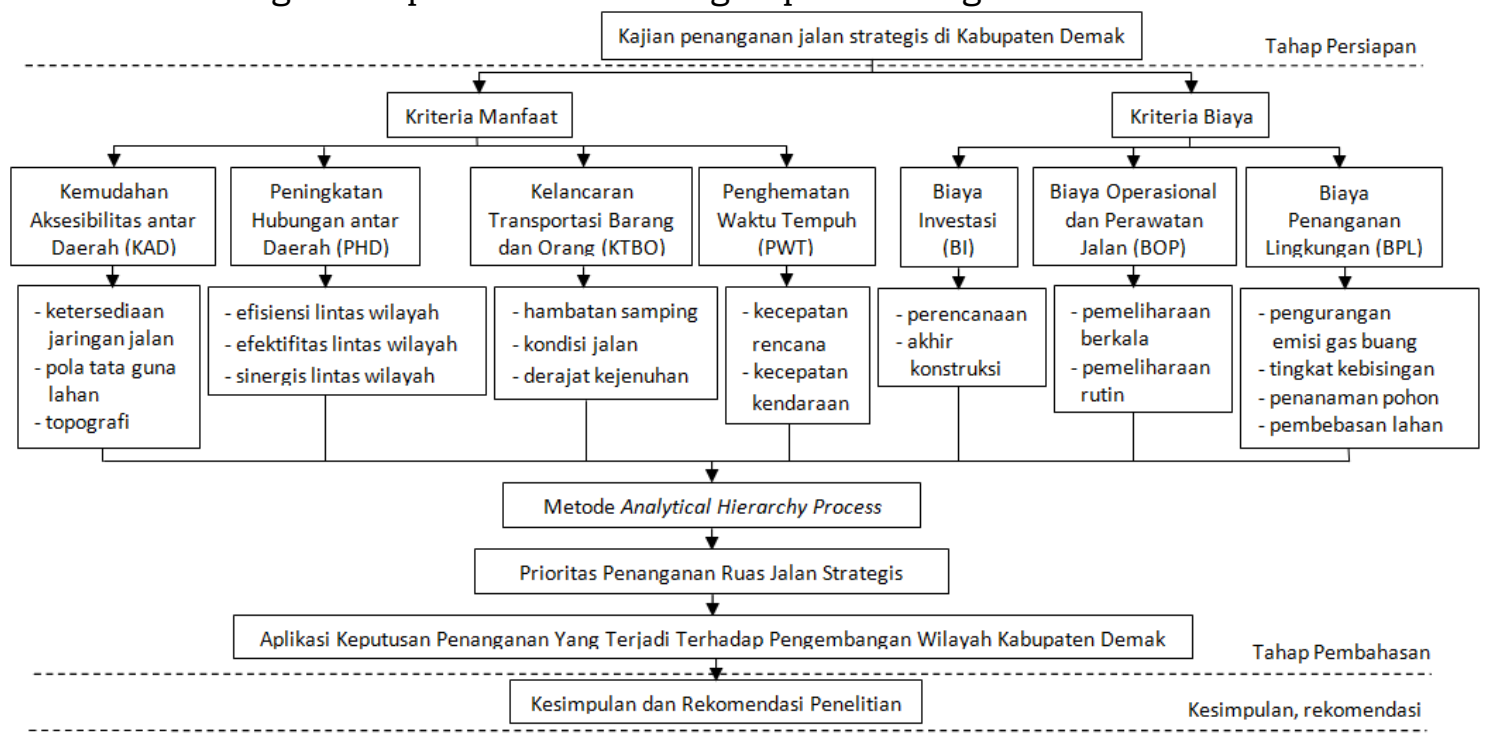

Gambar 1. Kerangka Analisis

Dalam penelitian ini dilakukan penyebaran kuesioner dengan wawancara langsung kepada responden yang mempunyai tugas, fungsi, dan pengalaman di bidang perencanaan hingga penangganan jalan kabupaten di Kabupaten Demak.

Penyebaran kuesioner kepada 11 (sebelas) responden dipilih secara purposive yaitu pemilihan responden berdasarkan pertimbangan dengan persyaratan responden yang dipilih memiliki pengetahuan, dan kompetensi dibidang penanganan jalan.

Dalam tugas pokok dan fungsi (tupoksi) dari Dinas Bina Marga Kabupaten Demak terbagi menjadi 3 (tiga) seksi yaitu (1) Seksi Peningkatan Jalan, dan Jembatan yang bertugas untuk meningkatkan kualitas ruas jalan sehingga tingkat pelayanan dapat dipertahankan, (2) Seksi Pemeliharaan Jalan, dan Jembatan yang bertugas untuk mempertahankan sistem jaringan yang tersedia agar tetap dalam kondisi yang memadai serta untuk pemulihan kondisi prasarana jalan, dan jembatan yang rusak melalui kegiatan pemeliharaan rutin, dan berkala, dan (3) Seksi Bina Teknik bertugas dalam membebaskan wilayah yang terisolir, dan desa terpencil agar terhubung pada kawasan yang berkembang serta potensial (Dinas Bina Marga DPUPPE Kabupaten Demak, 2013). Adapun respon expert yang dipilih dari Pemerintah Kabupaten Demak, antara lain : Kepala Bidang Bina Marga DPUPPE Kabupaten Demak-Bapak Akhmad Sugiharto, ST, MT (1 orang), Kepala Seksi Peningkatan Jalan, dan Jembatan Bina Marga DPUPPE Kabupaten Demak-Bapak Dul Muntolib, ST, MT (1 orang), Staf dari Seksi Peningkatan Jalan, dan Jembatan Bina Marga DPUPPE Kabupaten Demak-Bapak Sugeng Prayitno, dan Bapak Nasokhan, ST (2 orang). Kepala Seksi Pemeliharaan Jalan, dan Jembatan Bina Marga DPUPPE Kabupaten Demak-Bapak Agus Handaka, ST (1 orang), Staf dari Seksi Pemeliharaan Jalan, dan Jembatan Bina Marga DPUPPE Kabupaten Demak-Bapak S. Eko Widiantoro, ST, Bapak Supriyanto, dan Bapak Mutadi (3 orang). Kepala Seksi Bina Teknik Bina Marga DPUPPE Kabupaten Demak-Bapak Sularno, SST, MT (1 orang), Staf dari Seksi Bina Teknik Bina Marga DPUPPE Kabupaten Demak-Bapak Sugiyanto, ST, dan Bapak Mat Sholeh (2 orang). 


\section{Gambaran Umum}

Kabupaten Demak berada di bagian utara Provinsi Jawa Tengah, berbatasan langsung dengan Kota Semarang yang merupakan ibukota Provinsi Jawa Tengah serta sebagai pusat pemerintahan, dan perekonomian di Jawa Tengah. Letak daerah ini potensial sebagai daerah penyangga roda perekonomian Jawa Tengah. Kabupaten Demak juga berada pada jalur darat Pantai Utara Pulau Jawa dimana jalur ini merupakan jalur lalu lintas perdagangan yang ramai. Kabupaten Demak terletak di antara 6o 43'26"-7o 09'43" Lintang Selatan dan 110o 27'58"-110o 48'47' Bujur Timur dengan batas wilayah sebelah Utara ialah Kabupaten Jepara dan Laut Jawa, sebelah Timur berbatasan dengan Kabupaten Kudus dan Kabupaten Grobogan, sebelah Selatan adalah Kabupaten Grobogan dan Kabupaten Semarang, dan sebelah Barat berbatasan dengan Kota Semarang.

Secara administratif, luas wilayah Kabupaten Demak adalah 89.743 Ha. Kabupaten Demak terdiri atas 14 Kecamatan, 243 Desa, dan 6 Kelurahan, 512 Dusun, 6.326 Rukun Tetangga (RT) serta 1.262 Rukun Warga (RW). Dengan total penduduk pada tahun 2012 sebanyak 1.092.622 jiwa, terdiri dari 542.879 laki-laki (49,69\%), dan 549.743 perempuan $(50,31 \%)$. Jumlah penduduk ini meningkat sebanyak 15.761 orang atau sekitar $1,50 \%$ dari tahun sebelumnya. Kepadatan penduduk rata-rata Kabupaten Demak 1.218 jiwa/km2. Kecamatan terpadat secara berurutan adalah Kecamatan Mranggen (2.268 jiwa/km2), Kecamatan Demak (1.641 jiwa/km2), Kecamatan Wonosalam (1.318 jiwa/km2), Kecamatan Karangawen (1.292 jiwa/km2), Kecamatan Guntur (1.279 jiwa/km2), dan Kecamatan Sayung (1.269 jiwa/km2). Kecamatan lainnya kepadatannya di bawah 1200 jiwa/km2 dengan kepadatan terendah berada di Kecamatan Wedung, dengan kepadatan 718 jiwa/km2. Wilayah terluas dalam Kabupaten Demak adalah Kecamatan Wedung yaitu 9.876,0 Ha. Sedangkan kecamatan dengan wilayah terkecil adalah Kecamatan Kebonagung yaitu seluas $4.199 \mathrm{Ha}$. Dilihat dari ketinggian permukaan tanah dari permukaan laut (elevasi), wilayah Demak terletak mulai dari 0 meter sampai dengan 100 meter dari permukaan laut. Sedang dari tekstur tanahnya, wilayah Demak terdiri atas tekstur tanah halus (liat) seluas $49.066 \mathrm{Ha}$, dan tekstur tanah sedang (lempung) seluas $40.677 \mathrm{Ha}$. Sebagai daerah agraris yang kebanyakan penduduknya hidup dari pertanian, sebagian besar terdiri atas lahan sawah. Dan menurut penggunaan lahannya di Kabupaten Demak dibedakan menjadi 2 (dua) yaitu tanah sawah, dan tanah kering. Tanah sawah tahun 2012 ini mengalami peningkatan dari tahun sebelumnya kini memiliki luas $50.915 \mathrm{Ha}$ atau sebesar 56,73\% sedangkan sisanya seluas 38.828 Ha merupakan tanah kering. Tanah kering ini meliputi bangunan atau pekarangan, tegal atau kebun, dan sisanya diperuntukan sebagai tambak, hutan negara, hutan rakyat, dan keperluan lain -lain. Wilayah Kabupaten Demak sendiri memiliki jarak terjauh dari Barat ke Timur sepanjang $49 \mathrm{~km}$, dan jarak terjauh dari Utara ke Selatan panjangnya sebesar $41 \mathrm{~km}$.

\section{Penanganan Jalan Strategis Terhadap Perkembangan Wilayah Kabupaten Demak}

Suhardjo (2008) menggambarkan bahwa keterbatasan akses merupakan salah satu dari karakteristik kemiskinan. Keterbatasan aksesibilitas merupakan bagian dari lingkaran kemiskinan yang digambarkan Malassis (1975) dalam Bahrum (1995). Rendahnya nilai manfaat menyebabkan rendahnya investasi fisik, dan material serta investasi modal yang berlanjut terhadap tidak tumbuhnya sektor perekonomian yang menyebabkan kemiskinan. Dan peningkatan aksesibilitas merupakan salah satu cara untuk memotong siklus tersebut.Pendekatan peningkatan aksesibilitas dapat dilakukan melalui bidang transportasi berupa pembangunan, dan peningkatan jaringan jalan, peningkatan pelayanan umum, maupun pembangunan atau relokasi infrastruktur, serta peningkatan kualitas layanan. Keberhasilan pembangunan dalam bidang transportasi akan meningkatkan pertumbuhan 


\section{Analisis Prioritas Penanganan Ruas Jalan Strategis untuk Pengembangan Wilayah...}

ekonomi yang mampu meningkatkan taraf hidup masyarakat sehingga akan mempercepat pengembangan suatu wilayah. Peningkatan pertumbuhan perekonomian akan meningkatkan peranan sektor transportasi dalam menunjang pencapaian sasaran pembangunan, beserta hasil-hasilnya, sebaliknya fungsi sektor transportasi akan merangsang peningkatan pembangunan ekonomi, karena antara fungsi sektor transportasi, dan pembangunan ekonomi mempunyai hubungan timbal balik (Tamin, 2000). Kelangkaan sarana, dan prasarana transportasi pada pemanfaatan sumber daya dapat menimbulkan kesenjangan dalam pembangunan. Jika pemerintah tidak menyediakan sarana, dan prasarana transportasi yang diperlukan suatu wilayah, maka wilayah tersebut mungkin akan tetap bergantung pada daerah luar, dan akan mengalami pertumbuhan yang sangat terbatas, bahkan terisolir. Permasalahan transportasi sering berhubungan dengan jaringan jalan, khususnya penanganan jaringan jalan antar daerah, dalam penelitian ini antar kecamatan, dan antar desa di Kabupaten Demak. Sebagian jalan di Kabupaten Demak merupakan jalan penghubung antara Kota Semarang menuju Kota Purwodadi yang melewati Kecamatan Mranggen, Karangawen, dan Kecamatan Kebonagung, yang semuanya berpengaruh terhadap perkembangan Kabupaten Demak. Selain itu terdapat jalan-jalan penghubung antar desa, dan antar kecamatan dengan kondisi jalan yang bervariasi.

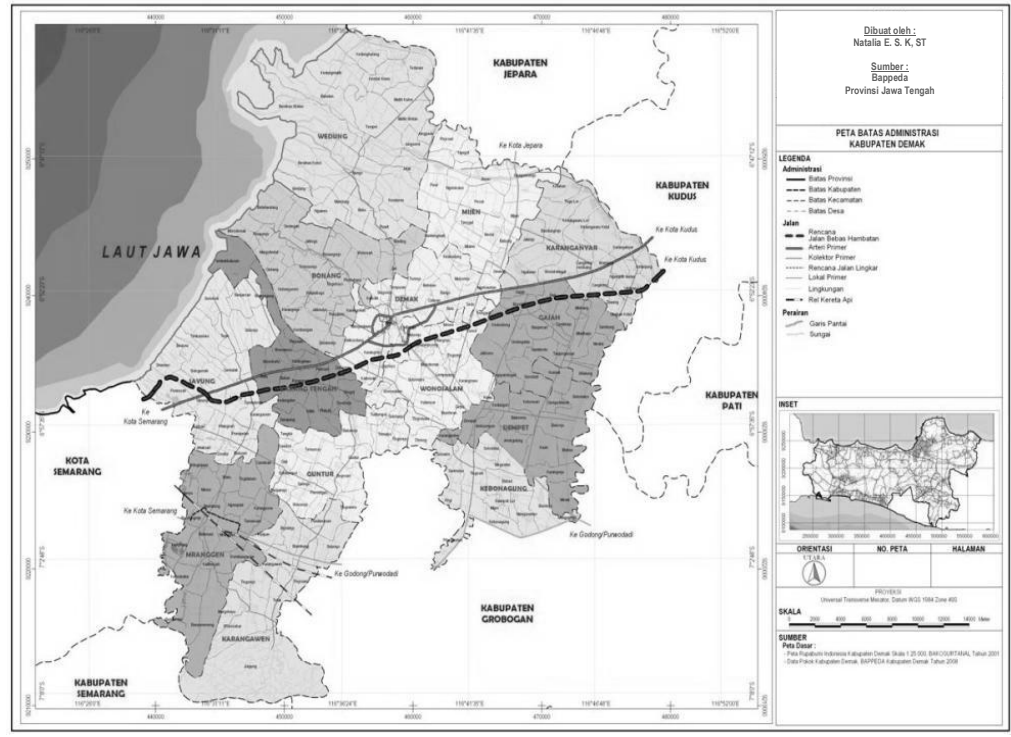

Sumber: Dinas Cipta Karya Provinsi Jawa Tengah, 2013

\section{Gambar 2. Wilayah Penelitian}

\section{Analisis}

\section{Analisis Hirarki Kriteria Manfaat dan Hirarki Kriteria Biaya}

Konsep penyusunan hirarki AHP (Analytical Hierarchy Process) untuk Kriteria Manfaat dan Kriteria Biaya dalam penentuan prioritas penanganan ruas jalan strategis di Kabupaten Demak dapat diuraikan berdasarkan kriteria-kriteria penentu yang diperoleh melalui penilaian responden expert melalui kuesioner. Uraian dimulai dari tujuan, kriteria, sub-kriteria, sub sub-kriteria, dan alternatif. Selengkapnya lihat Gambar 3 dan Gambar 4. 


\section{Analisis Skala Prioritas Penanganan Jalan Berdasarkan Kriteria Rasio Manfaat-Biaya (Benefit- Cost Ratio)}

Setelah sebelumnya dilakukan analisis, menggunakan program Expert Choice terhadap Kriteria Manfaat Menyeluruh serta terhadap Kriteria Biaya Menyeluruh, dengan metode AHP. Kemudian analisis dilanjutkan dengan membandingkan hasil Kriteria Manfaat Menyeluruh dengan hasil Kriteria Biaya Menyeluruh untuk masing-masing alternatif secara keseluruhan. Analisis mendalam pada tahap alternatif ini dimaksudkan untuk mengetahui ruas jalan strategis mana yang menjadi prioritas untuk dilaksanakan penanganan jalan strategis di oleh Kabupaten Demak, berikut ini penjelasan selengkapnya:

a. Prioritas pertama, jalan Mranggen-Bulusari

Dari analisis diperoleh perbedaan antara nilai Kriteria Manfaat Menyeluruh dengan nilai Kriteria Biaya Menyeluruh. Dimana nilai Kriteria Manfaat Menyeluruh mendapat peringkat tertinggi, sedangkan besaran Kriteria Biaya Menyeluruh pada posisi terendah. Artinya responden menilai bahwa biaya yang akan dikeluarkan tergolong rendah namun apabila dilakukan penanganan pada jalan strategis Mranggen-Bulusari akan didapat manfaat yang berlipat.

b. Prioritas kedua, jalan Karangawen-Pamongan

Pada analisis Kriteria Manfaat Menyeluruh jalan Karangawen-Pamongan mendapat peringkat ketiga, sedangkan pada Kriteria Biaya Menyeluruh berada diperingkat keempat. Sehingga menurut pendapat responden, ruas jalan tersebut memberi manfaat lebih tinggi untuk warga Kabupaten Demak dibanding dengan besaran biaya yang akan dikeluarkan jika dilakukan penanganan jalan.

c. Prioritas ketiga, jalan Gajah-Dempet

Menurut hasil AHP diketahui ruas jalan Gajah-Dempet memiliki prioritas lebih pada skor Kriteria Manfaat Menyeluruh daripada skor Kriteria Biaya Menyeluruh. Dimana jalan tersebut berada pada rangking kedua untuk skor Kriteria Manfaat Menyeluruh, dan rangking ketiga untuk skor Kriteria Biaya Menyeluruh. Sehingga apabila dilakukan penanganan jaringan jalan strategis maka jalan tersebut akan memberikan manfaat yang tinggi dibandingkan dengan aspek biaya yang akan dikeluarkan untuk penanganan jalan.

d. Prioritas keempat, jalan Demak-Bonang

Setelah dilakukan analisis Kriteria Manfaat Menyeluruh, dan analisis Kriteria Biaya Menyeluruh, jaringan jalan Demak-Bonang mendapat rangking kedua untuk Kriteria Biaya Menyeluruh, dan rangking keempat untuk Kriteria Manfaat Menyeluruh. Maka responden menilai bahwa apabila dilakukan penanganan pada jaringan jalan Demak-Bonang, biaya yang akan dikeluarkan lebih tinggi nilainya dibanding dengan manfaat yang diperoleh masyarakat, dan pemerintah Kabupaten Demak.

e. Prioritas kelima, jalan Bengkal-Karanganyar

Berdasarkan hasil analisis AHP yang telah dilakukan, diperoleh hasil bahwa besarnya Kriteria Biaya Menyeluruh berada diperingkat pertama, sedangkan Kriteria Manfaat Menyeluruh pada peringkat terakhir.Artinya penanganan jalan strategis BengkalKaranganyar memberikan dampak yang signifikan, karena biaya yang dikeluarkan sangat banyak, namun sedikit manfaat yang diperoleh.

Kemudian langkah selanjutnya untuk mengetahui ruas jalan strategis mana saja yang memperoleh nilai Rasio Manfaat-Biaya paling besar apabila dilaksanakan penanganan jalan oleh Pemerintah Kabupaten Demak ialah analisis perbandingan. Perhitungan analisis ini dilakukan dengan membagi hasil perbandingan Kriteria Manfaat Menyeluruh dengan hasil Kriteria Biaya Menyeluruh. Untuk memenuhi kriteria Rasio Manfaat-Biaya, maka hasil yang diperoleh harus sama dengan atau lebih besar dari 1 (satu) $(B / C>1)$. Selengkapnya lihat tabel berikut. 


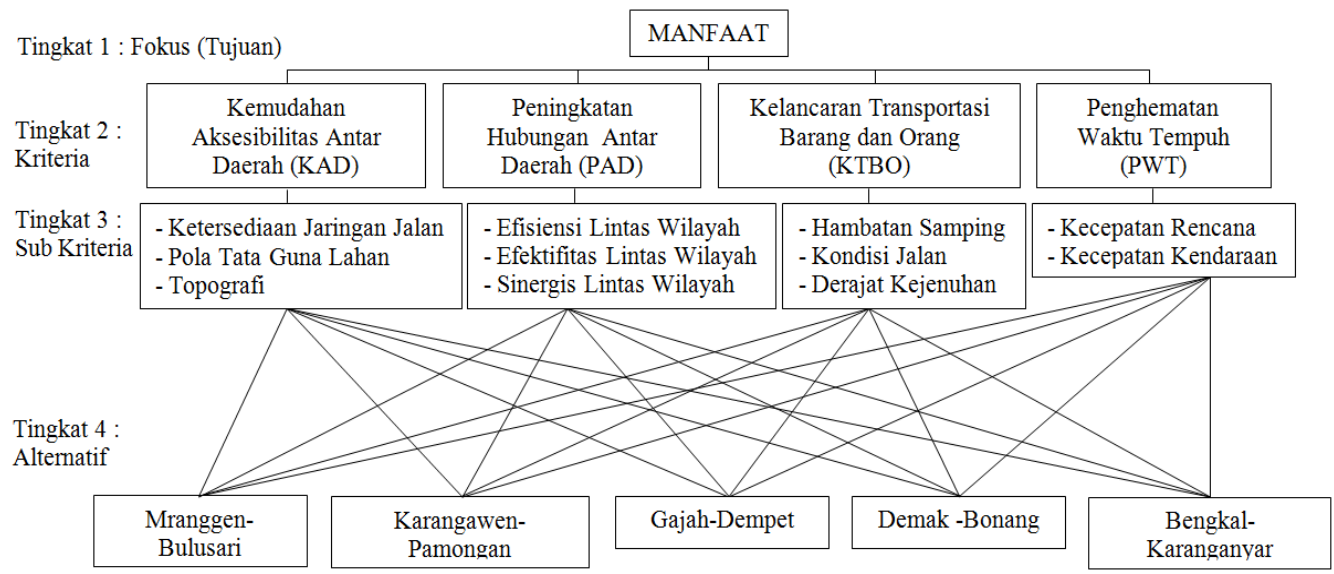

Gambar 3. Hirarki Kriteria Manfaat Prioritas Penanganan Jalan Strategis di Kabupaten Demak

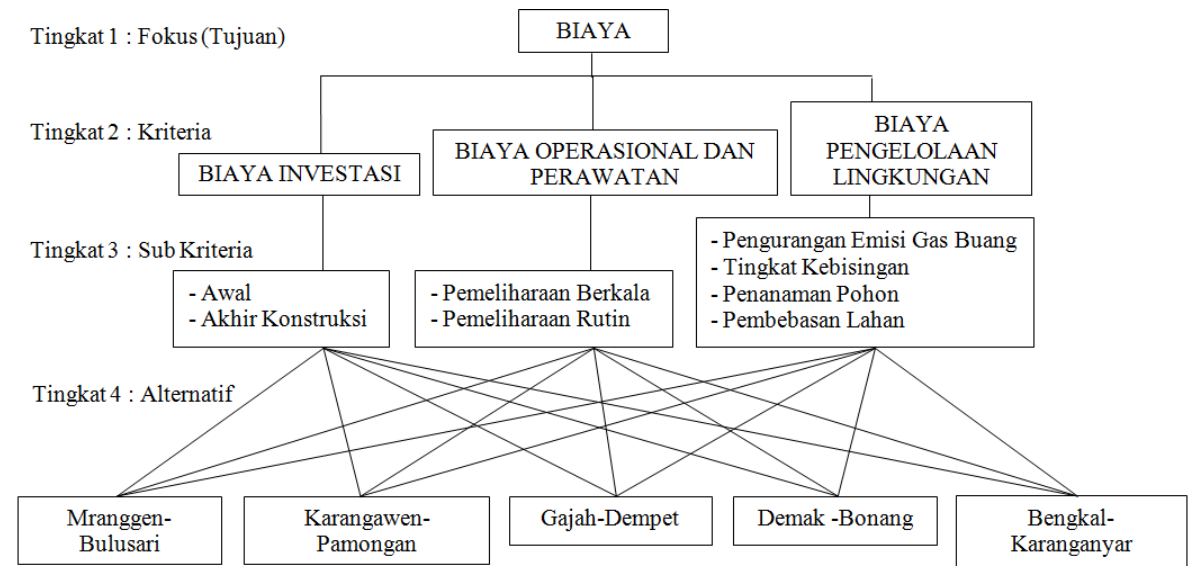

Gambar 4. Hirarki Kriteria Biaya Prioritas Penanganan Jalan Strategis di Kabupaten Demak

Tabel 1. Analisis Rasio Manfaat-Biaya Menyeluruh Tiap Ruas Jalan Strategis di Kabupaten Demak

\begin{tabular}{c|c|c|c}
\hline No. & Ruas Jalan & $\begin{array}{c}\text { Rasio Manfaat-Biaya } \\
(\mathbf{B} / \mathbf{C})\end{array}$ & $\begin{array}{c}\text { Ranking } \\
\text { Prioritas }\end{array}$ \\
\hline 1. & Mranggen-Bulusari & 4,309 & 1 \\
\hline 2. & Karangawen-Pamongan & 1,588 & 2 \\
\hline 3. & Gajah-Dempet & 1,091 & 3 \\
\hline 4. & Demak -Bonang & 0,613 & 4 \\
\hline 5. & Bengkal-Karanganyar & 0,434 & 5 \\
\hline
\end{tabular}

Menurut hasil analisis perbandingan tersebut diperoleh urutan prioritas penanganan jalan strategis berdasarkan besaran Rasio Kriteria Manfaat-Biaya Menyeluruh, yaitu:

1. Jalan Mranggen-Bulusari pada ranking pertama dengan perolehan nilai sebesar nilai 4,309 .

2. Jalan Karangawen-Pamongan pada ranking kedua dengan perolehan nilai sebesar nilai 1,588 . 
3. Jalan Gajah-Dempet pada ranking ketiga dengan perolehan nilai sebesar nilai 1,091.

4. Jalan Demak -Bonang pada ranking keempat dengan perolehan nilai sebesar nilai 0,613 .

5. Jalan Bengkal-Karanganyar pada ranking kelima dengan perolehan nilai sebesar nilai 0,434 .

Berdasarkan hasil Rasio Manfaat-Biaya tersebut, hanya terdapat 3 (tiga) ruas jalan strategis saja yang memenuhi kriteria Rasio Manfaat-Biaya, dimana manfaat per biaya hasilnya harus lebih atau sama dengan 1 (satu) $(B / C>1)$ dan menjadi prioritas Pemerintah Kabupaten Demak untuk dilakukan penanganan jalan strategis. Tiga jalan strategis tersebut adalah jalan Mranggen-Bulusari, jalan Karangawen-Pamongan, dan jalan Gajah-Dempet. Artinya responden menilai bahwa ketiga jalan strategis tersebut lebih memberikan banyak manfaat dalam mendukung aksesibilitas kegiatan masyarakat untuk pencapaian pertumbuhan ekonomi sosial yang lebih baik. Sedangkan sisa 2 (dua) jalan lainnya yaitu jalan Demak-Bonang, dan jalan Bengkal-Karanganyar tidak termasuk prioritas penanganan jalan strategis untuk dilaksanakan, karena mempunyai nilai Rasio Manfaat-Biaya yang lebih kecil dari 1 (satu).

\section{Penentuan Prioritas Penanganan Jalan Strategis Oleh Pemerintah Kabupaten Demak}

Mempertimbangkan letak geografis dan penduduk yang mayoritas bermatapencaharian di bidang pertanian, menjadikan Pemerintah Kabupaten Demak meletakkan sektor tersebut sebagai andalan dalam mencapai percepatan ekonomi. Oleh karena itu ketersediaan jalan yang baik menjadi fokus perhatian utama. Dalam pelayanannya, Pemerintah Kabupaten memiliki dana untuk penanganan jalan strategis, namun dalam jumlah yang terbatas. Karena banyak ruas jalan dalam kondisi rusak dan segera membutuhkan penanganan. Tetapi alokasi dana APBD dari Kabupaten Demak yang terbatas tersebut tidak bisa digunakan untuk pekerjaan penanganan seluruh jalan. Oleh karena itu diperlukan pengambilan keputusan untuk menentukan ruas jalan strategis mana saja yang mendapat prioritas penanganan. Selama ini yang dilakukan Pemerintah Kabupaten Demak khususnya Dinas Bina Marga di lingkungan Dinas Pekerjaan Umum, Perumahan, Pertambangan, dan Energi (DPUPPE) dalam melakukan skala prioritas penanganan jalan berbeda dengan pendekatan ilmiah yang digunakan peneliti. Keputusan yang diambil masih didominasi oleh pemegang kekuasaan, dimana usulan penanganan jalan yang diajukan dengan melihat faktor kondisi jalan, serta fungsinya sebagai jalan strategis dapat dijamin untuk sepenuhnya dipertimbangkan, dan disetujui agar segera dilakukan penanganan. Untuk perbedaan antara keputusan yang dibuat Pemerintah Kabupaten Demak dengan pendekatan ilmiah yang digunakan peneliti untuk penentuan prioritas penanganan jalan strategis di Kabupaten Demak, selengkapnya terinci dalam Tabel 2.

Tabel 2. Perbedaan Keputusan Prioritas Penanganan Jalan Strategis di Kabupaten Demak Tahun 2013

\begin{tabular}{c|c|c}
\hline No & $\begin{array}{c}\text { Pemerintah Kabupaten Demak (eksisting) } \\
\text { Tahun 2013 }\end{array}$ & $\begin{array}{c}\text { Metode Analytical Hierarchy Process (AHP) } \\
\text { Tahun 2013 }\end{array}$ \\
\hline 1 & Bersifat Deskriptif & Bersifat Deskriptif Kualitatif \\
\hline 2 & Tidak terstruktur & Terstruktur \\
\hline 3 & Tidak ada kriteria tertentu yang dipakai & Ada kriteria tertentu yang dipakai \\
\hline 4 & Tanpa dasar perhitungan yang jelas & $\begin{array}{c}\text { Dengan perhitungan yang jelas, melalui analisa } \\
\text { permasalahan yang kompleks dari kriteria, sub } \\
\text { kriteria, sub subkriteria, hingga tingkatan alternatif } \\
\text { tiap jalan strategis }\end{array}$ \\
\hline 5 & Kurang mempertimbangkan usulan dari tenaga ahli & Mengolah usulan dari tenaga ahli bidang jalan yang \\
\hline
\end{tabular}


108 Analisis Prioritas Penanganan Ruas Jalan Strategis untuk Pengembangan Wilayah...

\begin{tabular}{c|c|c}
\hline No & $\begin{array}{c}\text { Pemerintah Kabupaten Demak (eksisting) } \\
\text { Tahun 2013 }\end{array}$ & $\begin{array}{c}\text { Metode Analytical Hierarchy Process (AHP) } \\
\text { Tahun 2013 }\end{array}$ \\
\hline & bidang jalan & didapat melalui kuesioner \\
\hline 6 & $\begin{array}{c}\text { Keputusan penanganan jalan berdasarkan usulan } \\
\text { ad-hoc dari pihak-pihak tertentu pemegang } \\
\text { kekuasaan }\end{array}$ & $\begin{array}{c}\text { Keputusan penanganan jalan berdasarkan } \\
\text { pendekatan ilmiah menggunakan analisis data AHP }\end{array}$ \\
\hline 7 & Dana penanganan tidak tepat guna & Dana penanganan tepat guna \\
\hline 8 & $\begin{array}{c}\text { Keputusan penanganan jalan strategis yang } \\
\text { ditangani yaitu jalan Demak-Bonang, jalan Gajah- } \\
\text { Dempet, jalan Menco-Jetak, jalan Muka } \\
\text { Kabupaten, dan jalan Trengguli-Demung }\end{array}$ & $\begin{array}{c}\text { Keputusan penanganan jalan strategis yang } \\
\text { ditangani yaitu jalan Mranggen-Bulusari, jalan } \\
\text { Karangawen-Pamongan, jalan Demak-Bonang, } \\
\text { jalan Gajah-Dempet, dan jalan Bengkal- } \\
\text { Karanganyar }\end{array}$ \\
\hline
\end{tabular}

\section{Kesimpulan}

Setelah dilakukan analisa untuk mendapatkan prioritas penanganan jaringan jalan strategis di Kabupaten Demak dengan metode Analytical Hierarchy Process (AHP) dan pengolahan data menggunakan program Expert Choice, diperoleh beberapa kesimpulan sebagai berikut:

1. Hasil kuisioner terhadap 11 (sebelas) responden tenaga ahli bidang jalan menyatakan bahwa jalan strategis untuk dilakukan penanganan jalan oleh Dinas Bina Marga DPUPPE Kabupaten Demak antara lain Mranggen-Bulusari, Karangawen-Pamongan, Gajah-Dempet, Demak-Bonang, dan Bengkal-Karanganyar.

2. Dapat disimpulkan bahwa Kelancaran Transportasi Barang dan Orang sebesar $54,7 \%$ merupakan variabel terpenting dalam prioritas penanganan jaringan jalan strategis berdasarkan hasil Analisis Kriteria Manfaat, sedangkan berdasarkan Analisis Kriteria Biaya, variabel yang terpenting adalah Biaya Operasional dan Perawatan sebesar $61 \%$.

3. Untuk penanganan jaringan jalan strategis di Kabupaten Demak, berdasarkan analisis metode AHP, dan analisis Rasio Manfaat-Biaya $(B / C>1)$ dinyatakan dalam urutan sebagai berikut:

a. Jalan Mranggen-Bulusari, dengan perolehan skor Kriteria Manfaat sebesar 0,293 (peringkat 1) dan perolehan skor Kriteria Biaya sebesar 0,068 (peringkat 5). Sedangkan menurut hasil Analisis Rasio Manfaat-Biaya (B/C $>1)$, jalan ini mendapat prioritas 1 (pertama) untuk ditangani dengan nilai 4,309 dimana jalan yang terletak dekat pusat Kota Demak ini merupakan jalan strategis utama untuk dilakukan penanganan jalan. Karena menurut penilaian responden apabila dilakukan penanganan jalan pada jalan ini, maka biaya yang akan dikeluarkan tergolong rendah mengingat jalan tersebut sudah dibeton dengan kualitas cukup baik, dengan kondisi kerusakan jalan yang ada tidak banyak, tidak parah, dan apabila dilakukan penanganan tidak mengganggu kegiatan masyarakat, namun manfaat yang dihasilkan dapat berlipat dimana fungsinya sebagai jalan kolektor primer yang jalan menghubungkan antara Kota Semarang dengan Kota Purwodadi, serta penghubung antar kecamatan satu dengan yang lain sehingga memudahkan aksesibilitas masyarakat di Kabupaten Demak.

b. Jalan Karangawen-Pamongan, dengan perolehan skor Kriteria Manfaat Menyeluruh sebesar 0,189 (peringkat 3) dan perolehan skor Kriteria Biaya Menyeluruh sebesar 0,119 (peringkat 4). Sedangkan menurut hasil Analisis Rasio Manfaat-Biaya $(B / C>1)$, jalan ini menjadi jalan strategis dengan prioritas 2 (kedua) untuk dilakukan penanganan, dengan skor 1,588. Karena jalan 
tersebut berfungsi sebagai jalan penghubung utama antara 2 (dua) kecamatan dengan hasil produksi pertanian padi terbanyak dibanding kecamatan lainnya di Demak, dengan kondisi jalan tidak mantap hampir setengah dari total panjang jalannya menyebabkan distribusi hasil pertanian terganggu. Sehingga nantinya untuk kisaran biaya yang akan dikeluarkan dalam penanganan jalan strategis tersebut cukup banyak namun manfaat yang diperoleh dalam memperlancar arus produksi ke pusat-pusat pemasaran lebih tinggi

c. Jalan Gajah-Dempet, dengan perolehan skor Kriteria Manfaat sebesar 0,192 (peringkat 2), dan perolehan skor Kriteria Biaya sebesar 0,176 (peringkat 3). Sedangkan menurut hasil Analisis Rasio Manfaat-Biaya (B/C>1), jalan ini mendapat prioritas 3 (ketiga) untuk ditangani dengan nilai 1,091. Artinya apabila dilakukan penanganan jalan pada jalan strategis penghubung ibukota kecamatan satu dengan ibukota kecamatan lainnya ini, baik dari segi manfaat maupun dari segi biaya yang akan dikeluarkan, keduanya sama-sama memberi pengaruh secara signifikan. Dimana nilai manfaat yang diperoleh dengan nilai biaya jalan tersebut hasilnya sama besar dalam mendukung distribusi hasil pertanian agar berjalan baik serta lancar.

d. Jalan Demak-Bonang, dengan perolehan skor Kriteria Manfaat sebesar 0,173 (peringkat 4) dan perolehan skor Kriteria Biaya sebesar 0,282 (peringkat 2). Berkaitan dengan penilaian responden dengan Analisis Rasio Manfaat-Biaya $(B / C>1)$, diperoleh skor yang didapat tidak memenuhi syarat yaitu sebesar 0,613 atau kurang dari 1 (satu) serta berada pada ranking 4 (keempat) dari urutan prioritas penanganan jalan strategis secara keseluruhan. Karena biaya yang nantinya dikeluarkan untuk penanganan jalan ini akan sangat besar. Meskipun cukup manfaat yang didapat sebagai jalur penghubung antar kota Demak dengan Bonang. Sehingga dapat disimpulkan bahwa hasil manfaat tersebut berbanding terbalik dengan hasil biaya penanganannya.

e. Jalan Bengkal-Karanganyar, dengan perolehan skor Kriteria Manfaat sebesar 0,154 (peringkat 5), dan perolehan skor Kriteria Biaya sebesar 0,355 (peringkat 1). Sedangkan menurut hasil Analisis Rasio Manfaat-Biaya $(B / C>1)$, jalan ini mendapat prioritas 5 (kelima) untuk ditangani dengan nilai 0,434 (tidak memenuhi syarat karena kurang dari 1 (satu)). Jalan ini menempati urutan terakhir dalam penanganan jalan,karena manfaat yang diperoleh kurang signifikan dalam memicu pertumbuhan ekonomi sosial Kabupaten Demak, nantinya jalan ini membutuhkan dana penanganan jalan yang amat sangat besar untuk pemeliharaannya jika dilihat kelandaian jalan dengan beberapa tikungan, serta bentang yang paling panjang dari semua jalan strategis lainnya.

f. Sedangkan menurut eksisting di lapangan tahun 2013, jalan strategis yang ditangani oleh Pemerintah Kabupaten Demak antara lain jalan Demak-Bonang, Gajah-Dempet, Menco-Jetak, Muka Kabupaten, dan Trengguli-Demung. Hasil tersebut berbeda dengan penilaian responden tenaga ahli bidang jalan tentang ruas jalan strategis mana saja yang membutuhkan penanganan jalan, ruas jalan strategis. Menurut hasil analisis menggunakan AHP ruas jalan strategis yang diperoleh antara lain jalan Mranggen-Bulusari, Karangawen-Pamongan, GajahDempet, Demak-Bonang, dan Bengkal-Karanganyar. Dari hasil tersebut terdapat 2 (dua) jalan yang sama yaitu jalan Demak-Bonang, dan GajahDempet. Sementara 3 (tiga) jalan strategis lainnya berbeda. Hasil tersebut menyatakan bahwa masih ada beberapa hal yang ditentukan oleh pihak yang memiliki kekuasaan. Artinya pendekatan ilmiah yang dipakai belum sepenuhnya memiliki pengaruh dalam pengambilan keputusan, dan belum mendapatkan jaminan bahwa seluruh hasil analisis tersebut akan 
110 Analisis Prioritas Penanganan Ruas Jalan Strategis untuk Pengembangan Wilayah...

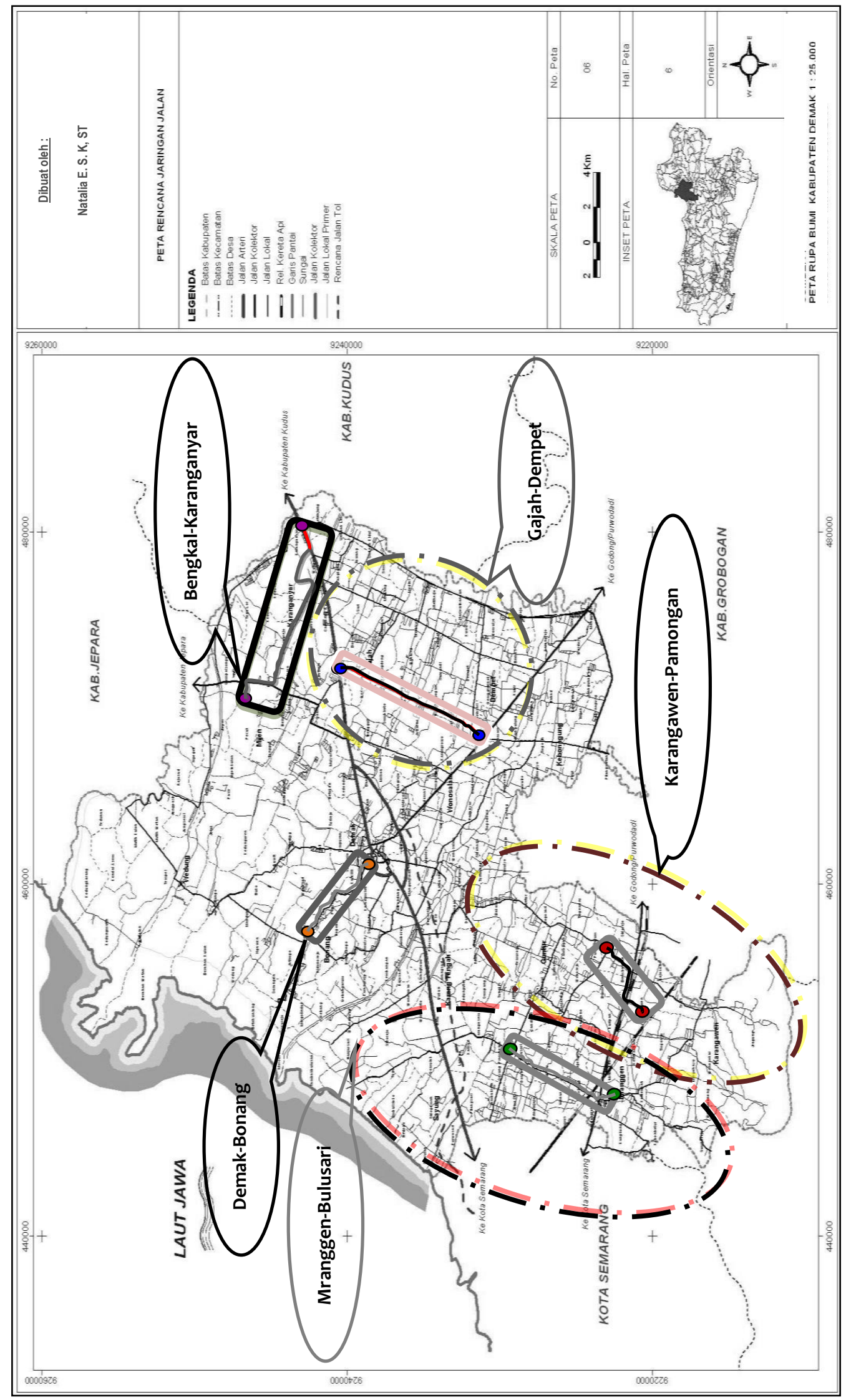

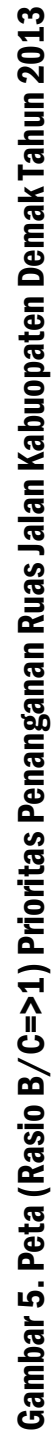


dipertimbangkan oleh pemegang kebijakan untuk dilaksanakan di lapangan.

g. Menurut hasil Analisis Rasio Manfaat-Biaya, dengan membandingkan hasil Kriteria Manfaat Menyeluruh dengan hasil Kriteria Biaya Menyeluruh diperoleh 3 (tiga) jalan strategis yang Rasio Manfaat-Biayanya lebih besar dari satu (B/C>l) yaitu jalan Mranggen-Bulusari sebesar 4,309 pada peringkat pertama, jalan Karangawen-Pamongan sebesar 1,588 pada peringkat kedua, dan jalan Gajah-Dempet sebesar 1,091 pada peringkat ketiga (Lihat Gambar 5).

\section{Rekomendasi}

Berkaitan dengan hasil penelitian maka ada beberapa rekomendasi dari hasil penelitian ini, yaitu :

1. Sesuai dengan hasil AHP, maka kepada pemerintah Kabupaten Demak disarankan untuk melakukan penanganan ruas jalan strategis untuk jalan Mranggen-Bulusari, Karangawen-Pamongan, dan jalan Gajah-Dempet karena memberikan Rasio Manfaat-Biaya yang lebih besar bagi pengembangan wilayah Kabupaten Demak.

2. Hasil penelitian ini kiranya dapat menjadi bahan masukan bagi DPUPPE Pemerintah Kabupaten Demak dalam pengambilan keputusan penentuan prioritas penanganan jalan strategis untuk penyusunan dokumen-dokumen perencanaan seperti RPJMD, RPJPD, dan Rencana Strategis (Renstra) Satuan Kerja Perangkat Daerah (SKPD) agar dana APBD yang terbatas menjadi tepat guna, serta bermanfaat bagi pemerataan ekonomi sosial Kabupaten Demak.

3. Penelitian ini diharapkan bisa menjadi dasar untuk penelitian lebih lanjut bagi kalangan akademis.

\section{Daftar Pustaka}

Azis, Iwan J. 1990. Analytic Hierarchy Process in the Benefit-Cost Framework: A Post Valuation of the trans Sumatera Highway Project. European Journal of Operation Research. Volume 48, No 1.

Losch, A. 1954. The Economics of Location. Yale University Press.

Mulyono, Sri. 1996. Teori Pengambilan Keputusan. Jakarta: Lembaga Penerbit Fakultas Ekonomi Universitas Indonesia.

Saaty, T. L. 2000. Fundamentals of Decision Making and Priority Theory, 2nd Edition. PA: RWS Publication. Pittsburgh.

Sudira, Putu. 2009. "Studi Mandiri Grounded Theory”. Tugas Akhir Tidak Diterbitkan. Program Pasca Sarjana Universitas Negeri Yogyakarta, Yogyakarta.

Tamin, Ofyar Z. 2000. Perencanaan dan Permodelan Transportasi. Bandung: Penerbit ITB. 
112 Analisis Prioritas Penanganan Ruas Jalan Strategis untuk Pengembangan Wilayah...

JURNAL WILAYAH DAN LINGKUNGAN, 2 (2), 99-112 